\title{
Prevalence of Transfusion Transmitted Infection among Blood Donors at Medical University in Bangladesh
}

\author{
Ara $\mathrm{F}^{1}$, Alam $\mathrm{ABMM}^{2}$, Rahman $\mathrm{M}^{3}$, Jahan $\mathrm{A}^{4}$, Yusuf $\mathrm{MA}^{5}$, Hassan $\mathrm{MS}^{6}$, Sonia $\mathrm{SF}^{7}$, Nasreen $\mathrm{Z}^{8}$, \\ Biswas $\mathrm{J}^{9}$
}

\begin{abstract}
Background: Blood transfusion is associated with a number of complications. Transfusion transmitted infections (TTI) are one of the major health problem in Bangladesh. Objective: The objective of the present study was to assess the status of transfusion transmitted infections among the apparently healthy donors. Methodology: This study we carried out among 12,294 blood donors from September 2009 to March 2010 at Department of Transfusion Medicine, Bangabandhu Sheikh Mujib Medical University (BSMMU), Dhaka, Bangladesh. All the samples were screened for hepatitis B surface antigen (HBsAg), hepatitis C virus (HCV), human immunodeficiency virus (HIV) 1 and 2, venereal disease research laboratory test (VDRL) and malaria to see the prevalence of TTI. Results: Prevalence of HBV, HCV, HIV, and syphilis were 0.009, 0.0004, 0.0001 and $0.0001 \%$ respectively. No blood donor tested showed positivity for malarial parasite. Conclusion: Mandatory screening of donated blood and use of sensitive screening test should be done to reduce TTI in Bangladesh. [J Shaheed Suhrawardy Med Coll, 2014;6(1):11-13]
\end{abstract}

Keywords: transmitted infection, blood donors

Received: March 2014; Revised: April 2014; Accepted: May 2014

\section{Introduction}

Transfusion of blood and blood components saves millions of lives worldwide each year ${ }^{1}$. It is well-known that blood transfusion is associated with a large number of complications ${ }^{2}$. In developing countries like Bangladesh blood safety remains an issue of major concern. Currently routine screening of healthy blood donors is regularly performed for hepatitis B virus (HBV), hepatitis C virus (HCV), human immunodeficiency virus (HIV), syphilis and malaria in Bangladesh. These strategies have been extremely effective; however, transmission of infectious diseases still occurs ${ }^{1,2}$.

HBV infection results in broad spectrum of disease from subclinical infection to fulminate hepatitis ${ }^{3}$. It can progress to chronic active hepatitis, cirrhosis of liver and hepatocellular carcinoma. Globally more than one million deaths occur from complication of HBV infection every year ${ }^{3}$. On the other hand $\mathrm{HCV}$ is emerging as one of the major health problem in Bangladesh. About 3\% of the world's population is infected with this virus accounting a total of 170 million HCV infected persons globally ${ }^{4}$. HIV is one of the human retroviruses that preferentially infects and kills helper (CD4) T lymphocytes, resulting in the loss of cell mediated immunity and a high probability that the host will develop opportunistic infections ${ }^{5}$. Treponema pallidum is transmitted from spirochete containing lesions of skin or mucous membrane like genitalia, mouth and rectum of an infected person to other persons by intimate contact; in addition to that it can be also transmitted from pregnant women to their fetuses ${ }^{6}$.

Malaria is caused by four Plasmodia species of which P. vivax and $\mathrm{P}$. falciparum are more common causes of malaria in

1. Dr. Ferdous Ara, Assistant Professor, Department of Transfusion Medicine, National Institute of Neurosciences \& Hospital, Dhaka

2. Dr. ABM Mashiul Alam, Lecturer, Department of Physiology, Faridpur Medical College, Faridpur

3. Dr. Manjuma Rahman, Associate Consultant, Department of Pathology \& Lab Medicine, Square Hospital Ltd, Dhaka

4. Dr. Asifa Jahan, Clinical Stuff, Department of Transfusion Medicine, Square Hospital Ltd, Dhaka

5. Dr. Abdullah Yusuf, Assistant Professor, Department of Microbiology, National Institute of Neurosciences \& Hospital, Dhaka

6. Dr. Mohammad Syaeed Hassan, Junior Consultant, Department of Neurology, National Institute of Neurosciences \& Hospital, Dhaka

7. Dr. Sheikh Farjana Sonia, MD (part-3) student, Bangladesh Institute of Child Health, Dhaka

8. Dr. Zubaida Nasreen, mo, Department of Transfusion Medicine, National Institute of Neurosciences \& Hospital, Dhaka

9. Dr. Jolly Biswas, Professor and Chairperson, Department of Transfusion Medicine, Bangabandhu Sheikh Mujib Medical University, Dhaka

\section{Correspondence}

Dr. Ferdous Ara, Assistant Professor, Department of Transfusion Medicine, National Institute of Neurosciences \& Hospital, Shar-E- Bangla Nagar, Agargaon, Dhaka1207, Bangladesh; Email: dr.sayeed@yahoo.com; Cell: +8801712103399

Funding Source: Self funding and institutions providing some technical support

Conflict of interest: None

Contributions by authors: FA, JB, ABMMA, preparation to manuscript preparation, FA, RM, MAY, MSH, SFS, ZN-Data analysis and preparation of manuscript as well as review of the paper 
Bangladesh. Worldwide malaria is one of the most common infectious diseases and a leading cause of death. This study was undertaken to know the prevalence of transfusion transmitted infection (TTI) among blood donors.

\section{Methodology}

This study was carried out among 12,294 blood donors from September 2009 to March 2010 in the Department of Transfusion Medicine at Bangabandhu Sheikh Mujib Medical University (BSMMU), Dhaka, Bangladesh. Blood samples were collected in pre-labeled pilot tube during collection of blood. Serum was separated from the clotted blood. All the blood donors who were underwent pretested blood grouping, Rh factor and cross matching with the blood of their respective recipient admitted in different wards of BSMMU were included as study population. Detection of HBsAg, anti HCV and anti HIV was done by ICT (Company name Excel USA). For screening of syphilis Rapid Precipitation Reaction (RPR) test (Company name Excel USA) was carried out. Detection of malaria was done by making thick and thin film on the glass slides stained with Giemsa stain and Leishman stain respectively. Statistical test was performed in Statistical Package of Social Science (Version 17.0). The qualitative data were expressed as frequency and percentage and quantitative data were expressed as mean and standard deviation (SD).

\section{Results}

The total number of blood donors was 12,294 cases. The age range of the donors was from 18 to 57 years. Out of 12294 respondents $44.33 \%$ were in the age group of 18 to $24,37.47 \%$ were in the age group of 25 to $34,15.10 \%$ were in the age group of 35 to 44 and rest $3.10 \%$ were in the age group of 45 to 57 years (Table 1).

Table 1: Distribution of Study Population according to age $(n=12294)$

\begin{tabular}{lcc}
\hline Age Group & Frequency & Percentage \\
\hline 18 to 24 years & & 44.3 \\
25 to 34 years & & 37.5 \\
35 to 44 years & & 15.1 \\
45 to 57 years & & 3.1 \\
Total & 12294 & $\mathbf{1 0 0 . 0}$ \\
\hline
\end{tabular}

*Mean $\pm \mathrm{SD}=25.25 \pm 12.364$ (Range $=18-57$ years)

It has been found that $11450(93.13 \%)$ were male and 844 $(6.87 \%)$ were female. Male female ratio was 13:1 (Table 2).

Table 2: Distribution of Study Population according to $\operatorname{Sex}(n=12294)$

\begin{tabular}{lcc}
\hline Gender & Frequency & Percentage \\
\hline Male & 11450 & 93.1 \\
Female & 844 & 6.9 \\
Total & $\mathbf{1 2 2 9 4}$ & $\mathbf{1 0 0 . 0}$ \\
\hline
\end{tabular}

* Male: female $=13: 1$
Out of 12,294 respondent's occupation, 5404(43.96\%) were students, $2680(21.80 \%)$ were non government service holder, 910(07.40\%) were government service holder and occupation of $1,990(16.18 \%)$ were business and 1,310 (10.66\%) were of other occupation (Table 3).

Table 3: Distribution of Study Population according to Occupation $(n=12294)$

\begin{tabular}{lcc}
\hline Occupation & Frequency & Percentage \\
\hline Student & 5404 & 43.96 \\
Non government service holder & 2680 & 21.8 \\
Government service holder & 910 & 7.4 \\
Business & 1990 & 16.2 \\
Other & 1,310 & 10.7 \\
Total & $\mathbf{1 2 2 9 4}$ & $\mathbf{1 0 0 . 0}$ \\
\hline
\end{tabular}

Prevalence of HBV, HCV, HIV, and syphilis were 0.009 , $0.0004,0.0001$ and $0.0001 \%$ respectively. No blood donor tested showed positivity for malarial parasite. Positivity rate of different transfusion transmissible diseases is shown (Table 4).

Table 4: Positive cases among the donors of Transfusion Medicine Unit of BSMMU $(n=12294)$

\begin{tabular}{lcc}
\hline Screening Tests & Frequency & Percentage \\
\hline HBsAg & 112 & 0.009 \\
Anti HCV & 6 & 0.0004 \\
VDRL & 1 & 0.0001 \\
Anti HIV & 1 & 0.0001 \\
Malarial parasite & 0 & 0.00 \\
Total & $\mathbf{1 2 0}$ & $\mathbf{0 . 0 0 9 6}$ \\
\hline
\end{tabular}

*HBsAg=Hepatitis B Virus surface antigen; HCV=Hepatitis $\mathrm{C}$ virus; VDRL=Venereal Disease Research Laboratory; $\mathrm{HIV}=$ Human immunodeficiency virus;

\section{Discussion}

Studies in the West have shown that the estimated risk of transfusion-transmitted HIV, HCV and to a lesser extend $\mathrm{HBV}$ infection via blood products is very $10 \mathrm{w}^{7-8}$. This is not same in developing countries, like Bangladesh. In the present study, the prevalence of HBsAg was $0.009 \%$, which is lower than the previous studies in Bangladesh. The prevalence of HBsAg in a study ${ }^{9}$ in Khulna Medical College Hospital, Khulna which is a tertiary care hospital $320 \mathrm{KM}$ from Dhaka was $1.39 \%$. In another study ${ }^{10}$ the prevalence was $2.19 \% 10$ at a tertiary care hospital named as Sir Salimullah Medical College situated in Dhaka. Sero-prevalence of $\mathrm{HBsAg}$ in various other Indian studies $^{11-12}$ has been shown to range between 1.86 and $4 \%$. Sero-prevalence of HBsAg in various studies ${ }^{13-14}$ in Pakistan has been shown to range between 1.55 and $8.4 \%$. In the present study the prevalence of sero-positivity for anti-HCV was $0.0004 \%$ which is also low comparing the previous findings. The prevalence of anti-HCV in a study ${ }^{9}$ 
in Khulna Medical College Hospital, Khulna was $0.024 \%$. In another study ${ }^{10}$ at Sir Salimullah Medical College, Dhaka the prevalence was $0.25 \%$. The global prevalence ${ }^{4}$ of chronic HCV-infection is estimated to be approaching $3 \%$. Extremely low anti-HCV prevalence $0 \%$ has been reported among the blood donors is UK and Scandinavia ${ }^{4}$. The highest prevalence $(28 \%)$ has been reported in Egypt $^{15}$. Indian studies ${ }^{11-12}$ indicate that sero-prevalence of HCV ranges between 0.4 and $1.1 \%$. Several studies ${ }^{13-14}$ in Pakistan showed that the sero-prevalence of $\mathrm{HCV}$ ranges between 0.07 and $4.9 \%$.

In this study it has been found that the sero-prevalence of

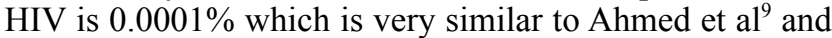
Saha et $\mathrm{al}^{10}$ in Bangladesh. The HIV sero-prevalence in Indian scenario ${ }^{16-17}$ has been reported between 0.2 and $1 \%$. Interestingly Pakistan has reported no transfusion transmitted HIV infection ${ }^{13-14}$. In the present study, the VDRL was positive in $0.0001 \%$ donor blood. The prevalence of VDRL in a study ${ }^{9}$ in Khulna Medical College Hospital, Khulna was $0.00 \%$. In another study ${ }^{10}$ in Sir Salimullah Medical College, Dhaka the prevalence was $0.17 \%$.

In the present study, prevalence of HBV, HCV, HIV, malaria and syphilis were fewer than previous studies. Prevalence of HBV was found to be the highest as compared with other transfusion-transmitted infection. HIV infection is a major public health problem world wide but it is still not common in Bangladesh, so attention should be paid toward the prevention of Hepatitis B and C virus as well as HIV.

\section{Conclusion}

Therefore, with the implementation of strict donor selection criteria, mandatory screening of donated blood and use of sensitive laboratory screening tests, it may be possible to reduce the incidence of TTI in Bangladesh.

\section{References}

1. Dodd RY, Notari EP, Stamer SL. Current prevalence and incidence of infectious disease markers and estimated window-period risk in the American Red Cross Blood Donor population. Transfusion 2002; 42:975-79
2. HG. Will blood transfusion ever be safe enough? JAMA 2000; 284:238-40

3. Kane M. Primary hepatocellular carcinoma and cirrhosis of liver resulting from. Chr. Hepatitis-B virus infection. Vaccine 1995; 13:S47

4. WHO Global surveillance and control of hepatitis-C. Report of a WHO consultation organized in collaboration with the viral hepatitis prevention board, Antwerp, Belgium. J Viral Hepat 1999; 6 : 35-47

5. Population Report. Controlling sexually transmitted disease series, 1993; 9: $1-15$

6. Husain M, Islam MN, Sultan M, Prevalence of HBV, HCV, HIV \& syphilis markers in pregnant women in Bangladesh. Journal of BSMMU 1998; $13: 17$

7. Alvarez M, Oyonarte S, Rodriguez PM, Hernandez JM. Estimated risk of transfusion-transmitted viral infections in Spain. Transfusion 2002; 42:99498

8. Pomper GJ, Wu Y, Synder EL. Risks of transfusion-transmitted infections. Curr Opin Hematol 2003; 10:412-18

9. Ahmed MU, Begum HA, Hossain T, Chakraborty P. Prevalence of Transfusion Transmitted Infection among Blood Donors. JAFMC Bangladesh. 2009;5(1):4-8

10. Saha SK, Banik RK, Saha MR, Habibullah MM, Mahtab MA. Prevalence of Transfusion Transmitted Infection in Healthy Blood Donors in Sir Salimullah Medical College. Euroasian Journal of Hepato-Gastroenterology, 2011;1(2):68-70

11. Chandrasekaran S, Palaniappan N, Krishnan V, Mohan G, Chandrasekaran N. Relative prevalence of hepatitis B viral markers and hepatitis $\mathrm{C}$ virus antibodies (anti-HCV) in Madurai, South India. Indian Journal of Medical Sciences 2000; 547:270-73

12. Srikrishna A, Sitalakshmi S, Damodar P. How safe are our safe donors? Indian Journal of Pathology and Microbiology 1999; 424:411-16

13. Khan MA, Rehman A, Ashraf M, Ali A, Ditta A. Prevalence of HBV, $\mathrm{HCV}$ and HIV in blood donors at Liaquatpur. Professional Med J 2006; 13:23-26

14. Mahmood MA, Khawar S, Anjum AH, et al. Prevalence of Hepatitis B, C and HIV infection in blood donors of Multan region. Ann King Edward Med Coll 2004; 10:459-61

15. Armstrong G, Alter M, McQuillang, et al. The past incidence of hepatitis $\mathrm{C}$ virus infection; implication for the future burden of chronic liver disease in United States. Hematol 2000; 31:777-82

16. Garg S, Mathur DR, Garg DK. Comparison of seropositivity of HIV, HBV, $\mathrm{HCV}$ and syphilis in replacement and voluntary blood donors in Western India. Indian Journal of Pathology and Microbiology 2001; 444:409-12

17. Paramjit K, Basu S. Transfusion-transmitted infections: Existing and emerging pathogens. Journal of Post Graduate Medicine 2005; 51:146-51 